\title{
Variation in the Nutrient Contents of Leaves, Bark, and Wood of Persian Oak Trees (Quercus brantii) Affected by Decline
}

\author{
Hamdeih Mohammadzadeh, ${ }^{\mathrm{a}}$ Javad Mirzaei, ${ }^{\mathrm{a}}$ Mohammad E. Farashiyani, ${ }^{\mathrm{b}}$ Forough \\ Soheili, ${ }^{a}$ Stephen Woodward, ${ }^{\mathrm{c}}$ Hazandy Abdul-Hamid, ${ }^{\mathrm{d}, \mathrm{e}}$ and Hamid R. Naji ${ }^{\mathrm{a}, *}$
}

\begin{abstract}
Tree decline is a physiological phenomenon resulting from climatic disturbances that involves damage to forest ecosystems. This study examined the effects of tree decline on nutrient concentrations in the leaves, bark, and wood of Persian oak (Quercus brantii) trees. Trees were categorized by decline severity (healthy, slight, moderate, and severe decline). Leaves were collected from the middle and outer parts of the crowns. Bark and wood samples were taken at breast height $(1.3 \mathrm{~m})$. The contents of $\mathrm{Mg}, \mathrm{Ca}, \mathrm{P}, \mathrm{Fe}, \mathrm{K}$, and $\mathrm{Na}$ were analyzed by atomic absorption spectrophotometry and flame photometry. As decline severity increased, the concentrations of $\mathrm{Mg}, \mathrm{Ca}, \mathrm{P}, \mathrm{Fe}, \mathrm{K}$, and $\mathrm{Na}$ in the foliage increased. However, the $\mathrm{P}$ and $\mathrm{K}$ in the bark and the $\mathrm{P}$ in the wood were lower in trees in the higher decline classes. Moreover, nutrient contents in the tissues examined varied across the different decline severities. The variations may have been due to defense mechanisms of the trees enhancing tolerance against induced stress. The results suggested that nutrient stoichiometry can reflect uptake in forest ecosystems and plantenvironmental stress relationships.
\end{abstract}

Keywords: Nutrient elements; Stoichiometry; Decline index; Persian oak; Plant tissues

Contact information: $a$ : Department of Forest Sciences, Ilam University, Ilam, Iran; $b$ : Research Institute of Forests and Rangelands, Agricultural Research, Education, and Extension Organization (AREEO),

Tehran, Iran; c: School of Biological Sciences, University of Aberdeen, Aberdeen, Scotland; d: Institute of Tropical Forestry and Forest Products (INTROP), Universiti Putra Malaysia, Seri Kembangan, Malaysia; e: Faculty of Forestry and Environment, Universiti Putra Malaysia, Seri Kembangan, Malaysia;

* Corresponding author: h.naji@ilam.ac.ir

\section{INTRODUCTION}

The semi-arid Zagros Forest in the west of Iran is dominated by oak and covers an area of 5 million hectares, representing $40 \%$ of the total Iranian forest area. Persian oak (Quercus brantii L.) is the most common tree species in the forest. This species is sensitive to changing environmental factors (Talebi et al. 2014). In recent years, these forests have been damaged by various natural factors, such as climate effects and pathogens. Drought is an important factor that causes mortality and decline in forest trees (Hosseini 2012). Lack of expected precipitation for a decade and global warming have resulted in drought, which, along with overgrazing, understory farming, and land use change, has encouraged outbreaks of destructive pests and diseases and the death of large numbers of oak trees in the Zagros forests. The phenomenon of decline has been reported in many provinces of the Zagros Region, especially in Ilam (Babaie-Kafaie 2004).

Comparing the quantities of nutrient elements in different tissues of healthy and declining trees is a reliable method of differentiating weakened from healthy trees 
(Niinemets 2010). During severe climatic or environmental disturbance, tree responses lead to changes in concentrations of many elements in different oak tissues (Hosseini 2017). In an oak stand affected by drought stress, trees vary in the damage sustained. The main factors that affect the response of oak to decline phenomena are tree physiology, nutrient availability and uptake, and tree vigor. As trees in older age classes are more susceptible to weakness and decline than younger trees, recovery is inhibited in the aftermath of pest attacks, pathogen attacks, or abiotic stresses, such as drought (Clatterbuck and Kauffman 2005).

Plant nutrition has direct and indirect roles in determining disease resistance (Daroub and Snyder 2007). Many diseases alter the nutritional balance in plants, and symptoms caused by abiotic and/or biotic factors are often difficult to differentiate (Römheld 2012). The response of trees to external factors can indicate changes in the nutrient contents of the affected organs. Therefore, it is useful to examine the response of forest ecosystems to environmental changes and stresses in terms of alterations in essential nutrients. Trees that are subject to varied stresses lose vigor, which can result in death (Lukac et al. 2010). Stress causes a change in water transfer (Silva et al. 2009), gas exchange and photosynthetic efficiency (Pagter et al. 2005), metabolism of carbohydrates, proteins, and amino acids, and accumulation of stress-related organic compounds in the plant (Šircelj et al. 2005). The consequent reduction in nutrient flow from the roots and leaves to other tissues impairs growth (Burke 2007).

Onset of decline symptoms can be induced by drought and severe water deficiency, severe winters or cold springs, and the intensification of the effects of decay-causing fungi that follow (Lakzian et al. 2013). The effects of nutrient deficiencies, principally phosphorous $(\mathrm{P})$, on hydraulic architecture, water relations, and stomatal behavior have been reported (Bucci et al. 2006; Samuelson et al. 2008; Ward et al. 2008). Macronutrients are generally considered the largest limiters of plant growth (Lebauer and Treseder 2008; Vitousek et al. 2010; Harpole et al. 2011). A study of sugar maple (Acer saccharum Marsh.) in the northeastern USA found that, on sites with low Mg, K and P, plus high Al and Mn concentrations in the soil, the trees exhibited symptoms of decline (Schaberg et al. 2006; Long et al. 2009; Bal et al. 2015). In addition, Ca deficiency was frequently observed in sugar maple foliage and soil in declining stands. Tavakolinekou et al. (2008) reported high amounts of $\mathrm{Na}$ in healthy Cupressus arizonica but low amounts of $\mathrm{K}$ in trees with severe drought stress. Nutrients, such as Na, P, K, Zn, and Fe did not vary in relation to dieback.

Measurement of the mineral and organic compounds in tree tissues provides information on the relationship between mineral uptake and vigor (Zarin Kafsh 2001). There has yet to be specific research on the nutritional contents of Persian oak in western Iran and the relationship between nutrition and decline in this species. Assessing the quantities of nutrients in tissues of $Q$. brantii that exhibit different severities of decline enables the identification of resistant individuals, which can be utilized to produce planting stock and detect the initial stages of decline in conservation programmes. Due to the increasing occurrence of decline in the Zagros forests, the work described here aimed to investigate variations in nutrients in the leaves, stem sapwood and bark of Persian oak trees that were exhibiting various decline symptoms. The results provided information on the uptake and the quantities of nutrients in the trees and their relationships with development decline. 


\section{EXPERIMENTAL}

\section{Study Area}

The Gachan forest area, which has a high prevalence of oak decline, was selected for this study. This 6.6-hectare forest has an elevation of $1821 \mathrm{~m}$, average precipitation of $585.2 \mathrm{~mm}$, is on a slope of approximately $35 \%$, and is located to the northeast of Ilam city at $33^{\circ} 38^{\prime} 55^{\prime \prime} \mathrm{N} ; 46^{\circ} 30^{\prime} 37^{\prime \prime} \mathrm{E}$ (Fig. 1). The main tree species present include Quercus brantii (Persian oak), Pistacia atlantica, Amygdalus scoparia, Acer monspessulanum, and Crataegus aronica. The first occurrence of decline as a consequence of drought in Zagros forest was reported in 2002. Symptoms on declining trees is noticeable in the foliage, usually with an initial deterioration of leaves turning pale green and yellow (Pourhashemi and Sadeghi 2021).

\section{Sampling Method}

The leaves, bark, and stem sapwood of healthy and declining oaks in different classes of decline were sampled in mid-June as the leaves matured. The selected trees were mature, natural regeneration, with diameters at breast height ranging between 40 and 50 $\mathrm{cm}$. The forest area sampled had uniform conditions (habitat, altitude, and topography). All trees were in the same biosocial classes. A minimum of 3 trees were selected for sampling from each level of decline. Selected trees were classified based on severity of crown dieback (class of defoliation) as follows: healthy trees (up to 5\%); slight (5\% to $33 \%$ ); moderate (34\% to $66 \%$ ); or dead (100\% defoliation) (Kabrick et al. 2008). Leaves were sampled from the middle and outer parts of the crowns (except for the final class) with telescopic secateurs; the inner bark (phloem) and sapwood were taken at breast height.

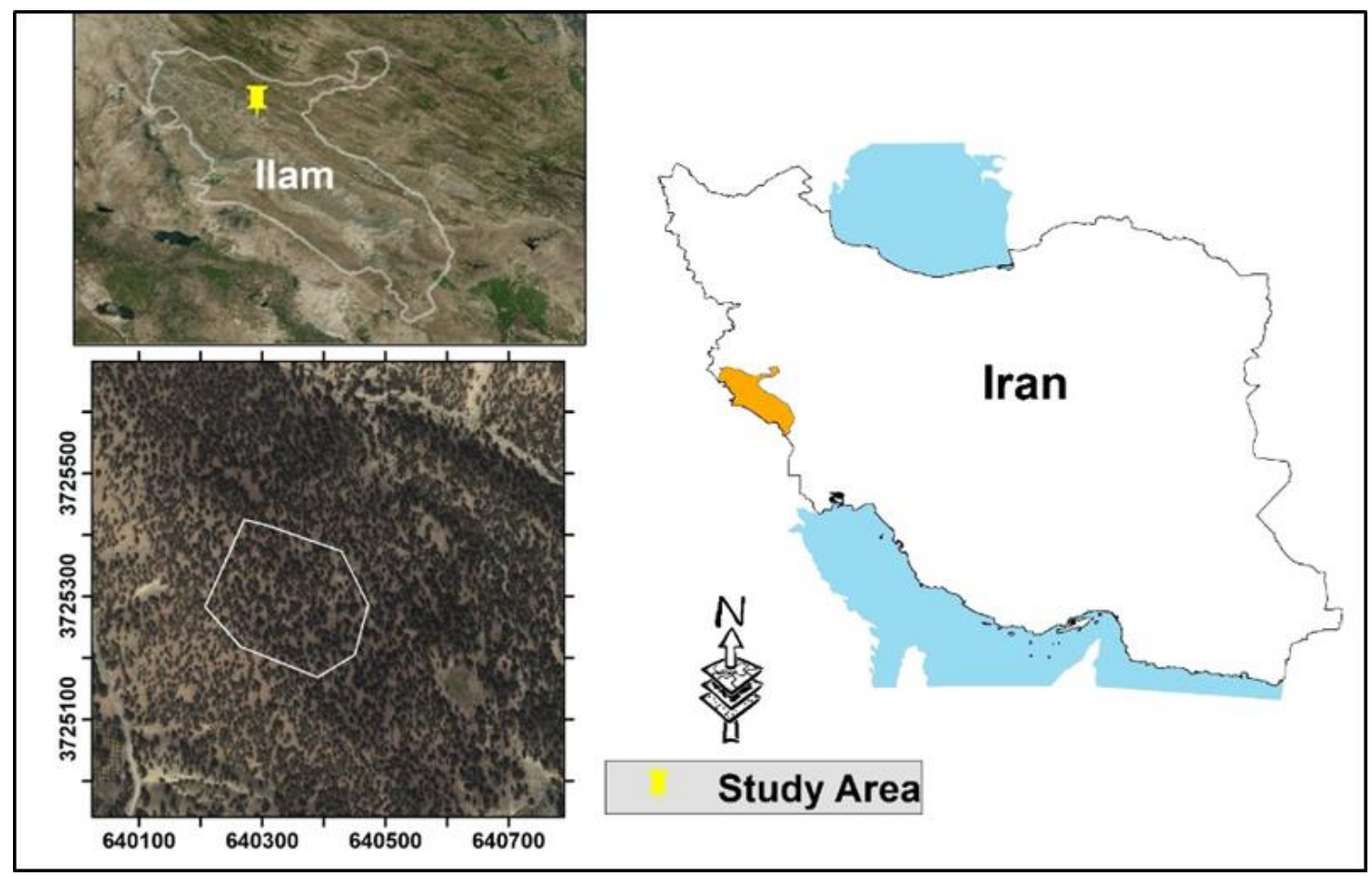

Fig. 1. Location of Gachan forest in llam 


\section{Sample Preparation for Nutrient Analyses}

To remove dust and other attached particles, sampled leaves were gently washed in distilled water before drying in an oven at $60 \pm 3{ }^{\circ} \mathrm{C}$ for approximately $48 \mathrm{~h}$. Dried samples were milled and passed through a sieve with a mesh of 35 to produce uniform particles of equal size. Five $( \pm 0.001) \mathrm{g}$ dried powder was ashed in an electric oven (Shimifan F.47, Tehran, Iran) at $500{ }^{\circ} \mathrm{C}$ for $5 \mathrm{~h}$. To measure $\mathrm{Mg}, \mathrm{Ca}, \mathrm{P}, \mathrm{Fe}, \mathrm{K}$, and $\mathrm{Na}$ with a dry digestion method, the ash was combined with $20 \mathrm{~mL}$ of $\mathrm{HCl}(1 \mathrm{~N})$, passed through Whatman ${ }^{\circledR} 42$ filter paper (Whatman Inc., Piscataway, NJ, USA), and the volume adjusted to $100 \mathrm{~mL}$ (Miles et al. 2001). Thereafter, the following devices were used to measure the content of each element: $\mathrm{Fe}$ and $\mathrm{Mg}$ were measured via atomic absorption (Analytikjena NOVAA 400P, Jena, Germany); P was measured via spectrophotometry (BT1500 Autoanalyser, Biotecnica Instruments S.p.A, Rome, Italy); $\mathrm{Ca}, \mathrm{Na}$, and $\mathrm{K}$ were measured via flame photometry (Jen way 85OS, Staffordshire, England).

\section{Statistical Analysis}

The normality and homogeneity of the data were evaluated using Shapiro-Wilk and Levene's tests, respectively. Data were subjected to one-way analysis of variance (ANOVA) and means compared using the Tukey test at a significance level of $0.01 \%$. Comparisons of the mean concentrations of nutrient elements $(\mathrm{Mg}, \mathrm{Ca}, \mathrm{P}, \mathrm{Fe}, \mathrm{K}$, and $\mathrm{Na}$ ) in the leaves, bark and sapwood of oaks in the different decline classes were made using the Tukey test. The data were analyzed using IBM SPSS ver. 24., Chicago, IL, USA.

\section{RESULTS AND DISCUSSION}

Quantities of nutrients found in leaf, bark, and sapwood samples of $Q$. brantii based on classes of decline are shown in Table 1. There was no significant effect of decline class on $\mathrm{Mg}$ or $\mathrm{K}$ contents in leaves. However, there were significant differences in $\mathrm{Ca}, \mathrm{P}, \mathrm{Fe}$, and $\mathrm{Na}(\mathrm{P}<0.01)$ between decline classes. Concentrations of $\mathrm{Mg}, \mathrm{Ca}, \mathrm{P}, \mathrm{Fe}, \mathrm{K}$, and $\mathrm{Na}$ in the bark of sampled trees differed significantly $(\mathrm{P}<0.01)$. The effects of decline on $\mathrm{Mg}$, $\mathrm{Ca}, \mathrm{Fe}$, and $\mathrm{Na}$ concentrations were significant in the sapwood $(\mathrm{P}<0.01)$, but no significant differences were observed among $\mathrm{K}$ or $\mathrm{P}$. The highest and lowest differences in nutrient elements in leaves were $\mathrm{Ca}$ and $\mathrm{Mg}$, respectively. In bark, the highest and lowest differences in nutrient elements were $\mathrm{Fe}$ and $\mathrm{Ca}$, respectively. In the sapwood, $\mathrm{Mg}$ and $\mathrm{K}$ had the highest and lowest differences in nutrient elements, respectively.

\section{Nutrients in Leaves}

No significant differences were observed among the $\mathrm{Mg}$, $\mathrm{P}$, or $\mathrm{K}$ concentrations in the leaves (Table 2). However, quantities of $\mathrm{Ca}, \mathrm{Fe}$, and $\mathrm{Na}$ differed significantly between decline classes. Generally, concentrations of $\mathrm{Mg}, \mathrm{Ca}, \mathrm{P}, \mathrm{Fe}$, and $\mathrm{Na}$ increased as tree decline increased $(\mathrm{P}<0.01)$.

\section{Nutrients in Bark}

Compared to healthy trees, no significant differences were detected between the concentrations of $\mathrm{Mg}$ in the inner bark tissues of trees with decline severities of $30 \%$ and $70 \%$. However, a significant difference $(a=0.004)$ was observed for trees with severe decline (100\%). In most of the tissues sampled, concentrations of Ca were significantly higher in declined than healthy trees $(\mathrm{P}<0.01)$. 
Table 1. ANOVA Results of Nutrient Contents of Quercus brantii Leaves, Inner Bark, and Wood in Relation to Decline Class

\begin{tabular}{|c|c|c|c|c|c|c|c|c|}
\hline \multicolumn{9}{|c|}{ Mean Square } \\
\hline Tissue & $\begin{array}{l}\text { Source of } \\
\text { Variation }\end{array}$ & Df & $\begin{array}{c}\mathrm{Mg} \\
(\mathrm{ppm})\end{array}$ & $\begin{array}{c}\mathrm{Ca} \\
(\mathrm{ppm})\end{array}$ & $\begin{array}{c}\mathrm{P} \\
(\mathrm{ppm})\end{array}$ & $\begin{array}{c}\mathrm{Fe} \\
(\mathrm{ppm})\end{array}$ & $\begin{array}{c}\mathrm{K} \\
(\mathrm{ppm})\end{array}$ & $\begin{array}{c}\mathrm{Na} \\
(\mathrm{ppm})\end{array}$ \\
\hline \multirow{4}{*}{ Leaf } & Decline & 2 & $15.44^{\mathrm{ns}}$ & $10.33^{* *}$ & $19.33^{* *}$ & $0.24^{* \star}$ & $1314.1^{\text {ns }}$ & $8.5^{* *}$ \\
\hline & $\begin{array}{l}\text { Coefficient of } \\
\text { variation }\end{array}$ & - & 5.81 & 20.9 & 12.2 & 9.92 & 7.48 & 11.94 \\
\hline & Error & 4 & 15.78 & 180.1 & 14.33 & 0.01 & 829.4 & 0.52 \\
\hline & $\begin{array}{c}\text { Significance } \\
\text { level }\end{array}$ & - & 0.45 & 0.001 & 0.01 & 0.007 & 0.31 & 0.01 \\
\hline \multirow{4}{*}{ Bark } & Decline & 3 & $19.97^{* *}$ & $3000^{* *}$ & $11.55^{\star *}$ & $0.14^{* *}$ & $60.75^{* *}$ & $41.23^{* *}$ \\
\hline & $\begin{array}{l}\text { Coefficient of } \\
\text { variation }\end{array}$ & - & 29.48 & 9.72 & 24.85 & 35.85 & 21.03 & 19.43 \\
\hline & Error & 6 & 12.13 & 75.42 & 0.29 & 0.005 & 301.75 & 1.78 \\
\hline & $\begin{array}{c}\text { Significance } \\
\text { level }\end{array}$ & - & 0.003 & 0.000 & 0.000 & 0.001 & 0.002 & 0.001 \\
\hline \multirow[b]{4}{*}{ Wood } & Decline & 3 & $259.4^{* *}$ & $501.6^{* *}$ & $6.1^{\mathrm{ns}}$ & $0.07^{* *}$ & $267.9^{\text {ns }}$ & $72.44^{\star *}$ \\
\hline & $\begin{array}{l}\text { Coefficient of } \\
\text { variation }\end{array}$ & - & 56.73 & 20.96 & 18.71 & 22.93 & 8.48 & 28.89 \\
\hline & Error & 6 & 7.29 & 216.8 & 2.89 & 0.003 & 165.9 & 3.81 \\
\hline & $\begin{array}{c}\text { Significance } \\
\text { level }\end{array}$ & - & 0.0 & 0.001 & 0.2 & 0.001 & 0.28 & 0.002 \\
\hline
\end{tabular}

Table 2. Comparison of Different Elements (Means \pm SE) in the Leaves, Bark and Wood of Persian Oak Trees in Different Classes of Decline Based on Tukey Test

\begin{tabular}{|c|c|c|c|c|c|c|c|}
\hline $\begin{array}{l}\text { Tree } \\
\text { Organ }\end{array}$ & DCD & $\begin{array}{c}\mathrm{Mg} \\
(\mathrm{ppm})\end{array}$ & $\begin{array}{c}\mathrm{Ca} \\
(\mathrm{ppm})\end{array}$ & $\begin{array}{c}\mathbf{P} \\
(\mathrm{ppm})\end{array}$ & $\begin{array}{c}\mathrm{Fe} \\
(\mathrm{ppm})\end{array}$ & $\begin{array}{c}\mathrm{K} \\
(\mathrm{ppm})\end{array}$ & $\begin{array}{c}\mathrm{Na} \\
(\mathrm{ppm})\end{array}$ \\
\hline \multirow[t]{3}{*}{ Leaf } & Healthy & $\begin{array}{c}69.7 \\
\pm 1.15^{a} \\
\end{array}$ & $\begin{array}{l}192.3 \\
\pm 0.57^{c}\end{array}$ & $\begin{array}{c}66.3 \\
\pm 2.08^{a}\end{array}$ & $\begin{array}{l}2.4 \\
\pm 0^{\mathrm{b}}\end{array}$ & $\begin{array}{c}369.3 \\
\pm 1.15^{a}\end{array}$ & $\begin{array}{c}12.0 \\
\pm 0.45^{\mathrm{b}}\end{array}$ \\
\hline & $30 \%$ & $\begin{array}{c}68.7 \\
\pm 7.02^{\mathrm{a}} \\
\end{array}$ & $\begin{array}{c}254.3 \\
\pm 10.06^{\mathrm{b}} \\
\end{array}$ & $\begin{array}{r}55.0 \\
\pm 3.6^{\mathrm{b}} \\
\end{array}$ & $\begin{array}{c}2.8 \\
\pm 0.2^{\mathrm{a}} \\
\end{array}$ & $\begin{array}{c}408.3 \\
\pm 20.84^{\mathrm{a}} \\
\end{array}$ & $\begin{array}{c}13.8 \\
\pm 1.34^{\mathrm{ab}} \\
\end{array}$ \\
\hline & $70 \%$ & $\begin{array}{l}73.0 \\
\pm 1^{\text {a }}\end{array}$ & $\begin{array}{c}309.7 \\
\pm 25.92^{\mathrm{a}}\end{array}$ & $\begin{array}{c}70.7 \\
\pm 5.5^{a}\end{array}$ & $\begin{array}{l}3.0 \\
\pm 0.06^{a}\end{array}$ & $\begin{array}{c}402.0 \\
\pm 41.32^{\mathrm{a}}\end{array}$ & $\begin{array}{c}15.3 \\
\pm 0.37^{a}\end{array}$ \\
\hline \multirow[t]{4}{*}{ Bark } & Healthy & $\begin{array}{l}24.30 \\
\pm 1.52^{\mathrm{b}}\end{array}$ & $\begin{array}{l}258.3 \\
\pm 3.51^{\mathrm{b}}\end{array}$ & $\begin{array}{c}10 \\
\pm 0.11^{\mathrm{a}}\end{array}$ & 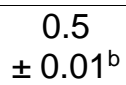 & $\begin{array}{l}219.7 \\
\pm 0.57^{a}\end{array}$ & $\begin{array}{l}20.9 \\
\pm 1^{\mathrm{a}}\end{array}$ \\
\hline & $30 \%$ & $\begin{array}{c}17.70 \\
\pm .057^{\mathrm{b}}\end{array}$ & $\begin{array}{c}320.3 \\
\pm 13.31^{a} \\
\end{array}$ & $\begin{array}{c}5.3 \\
\pm 0.57^{c} \\
\end{array}$ & $\begin{array}{c}0.5 \\
\pm 0.02^{\mathrm{b}} \\
\end{array}$ & $\begin{array}{c}217.3 \\
\pm 14.29 \mathrm{a} \\
\end{array}$ & $\begin{array}{c}14.6 \\
\pm 1.53^{\mathrm{b}} \\
\end{array}$ \\
\hline & $70 \%$ & $\begin{array}{c}26.70 \\
\pm 1.57^{b}\end{array}$ & $\begin{array}{c}324.3 \\
\pm 8.08^{a}\end{array}$ & $\begin{array}{r}8.0 \\
\pm 1^{\mathrm{b}}\end{array}$ & $\begin{array}{l}0.5 \\
\pm 0.02^{b}\end{array}$ & $\begin{array}{c}239.7 \\
\pm 23.54^{\mathrm{a}}\end{array}$ & $\begin{array}{c}15.3 \\
\pm 1.62^{b}\end{array}$ \\
\hline & $100 \%$ & $\begin{array}{c}37.00 \\
\pm 6.24^{\mathrm{a}}\end{array}$ & $\begin{array}{c}319.7 \\
\pm 10.06^{a}\end{array}$ & $\begin{array}{c}6.7 \\
\pm 0.57^{b c}\end{array}$ & $\begin{array}{l}1.0 \pm \\
0.14^{a}\end{array}$ & $\begin{array}{c}137.7 \\
\pm 13.5^{\mathrm{b}}\end{array}$ & $\begin{array}{c}21.8 \\
\pm 0.66^{a}\end{array}$ \\
\hline \multirow{4}{*}{$\begin{array}{l}\text { Sapw } \\
\text { ood }\end{array}$} & Healthy & $\begin{aligned} & 6.2 \\
\pm & 0.26^{b}\end{aligned}$ & $\begin{array}{c}161.3^{b c} \\
\pm 0.57\end{array}$ & $\begin{array}{l}11.0^{\mathrm{a}} \\
\pm 0.17\end{array}$ & $\begin{array}{l}0.5^{b} \\
\pm 0\end{array}$ & $\begin{array}{l}173.0^{a} \\
\pm 2.64\end{array}$ & $\begin{array}{c}9.9 \\
\pm 3.2^{\mathrm{b}}\end{array}$ \\
\hline & $30 \%$ & $\begin{aligned} & 8.7 \\
\pm & 2.08^{b}\end{aligned}$ & $\begin{array}{c}149.7 \\
\pm 1.52^{\mathrm{c}}\end{array}$ & $\begin{array}{c}9.3 \\
\pm 1.52^{\mathrm{a}}\end{array}$ & $\begin{array}{l}0.6 \\
\pm 0.05^{\mathrm{b}}\end{array}$ & $\begin{array}{c}195 \\
\pm 9.84^{a}\end{array}$ & $\begin{array}{c}19.9 \\
\pm 0.7^{a}\end{array}$ \\
\hline & $70 \%$ & $\begin{array}{c}22.0 \\
\pm 4.6^{a}\end{array}$ & $\begin{array}{l}194.0 \pm \\
26.51^{\mathrm{b}}\end{array}$ & $\begin{array}{l}11.0 \pm \\
1.73^{a}\end{array}$ & $\begin{array}{l}0.8 \pm \\
0.08^{a}\end{array}$ & $\begin{array}{c}179.3 \pm \\
20^{\mathrm{a}}\end{array}$ & $\begin{array}{l}20.3^{a} \\
\pm 0.89\end{array}$ \\
\hline & $100 \%$ & $\begin{array}{r}24.7^{a} \\
\pm 2.08\end{array}$ & $\begin{array}{c}241.0^{\mathrm{a}} \\
\pm 13.22 \\
\end{array}$ & $\begin{array}{l}8.0^{\mathrm{a}} \\
\pm 2 \\
\end{array}$ & $\begin{array}{l}0.9^{a} \\
\pm 0.02\end{array}$ & $\begin{array}{l}186.3^{\mathrm{a}} \\
\pm 20.59\end{array}$ & $\begin{array}{l}15.0^{a} \\
\pm 0.85\end{array}$ \\
\hline
\end{tabular}

Note: The superscript letters in each column for each tissue indicate significant differences $(P>0.01)$ between the means of the nutrients; DCD: Classes of decline; SE: Standard error 
There were significant differences between $\mathrm{P}$ concentrations in bark tissues among all decline classes, but no specific pattern was discernable. Trees in the healthy, 30\% decline and $70 \%$ decline classes differed significantly in Fe concentrations compared to those in the $100 \%$ decline class $(\mathrm{P}<0.01)$. Fe concentrations were highest in trees in the $100 \%$ decline class (Table 2).

Similar to the differences in Fe concentrations, there was a significant difference between $\mathrm{K}$ concentrations in trees with severe decline (100\%) and those in other decline classes, and healthy trees $(\mathrm{P}<0.01)$. Otherwise, variations in $\mathrm{K}$ concentration showed no specific pattern. There was no significant difference between the concentrations of $\mathrm{Na}$ in healthy compared with $100 \%$ declined trees (Table 2).

\section{Nutrients in Sapwood}

Concentrations of $\mathrm{Mg}, \mathrm{Ca}, \mathrm{Fe}$, and $\mathrm{Na}$ did not vary significantly across different decline classes (Table 2). $\mathrm{Mg}$ and Fe concentrations were significantly higher in the sapwood of trees in the $70 \%$ and $100 \%$ decline classes than in other classes $(\mathrm{P}>0.01)$. In addition, the $\mathrm{Ca}$ and $\mathrm{Na}$ concentrations were significantly higher in the $100 \%$ decline class than in other decline classes $(\mathrm{P}<0.01)$.

Magnesium is of great importance in chlorophyll and is, therefore, crucial to photosynthesis (Jones and Huber 2007). The relationship between $\mathrm{Mg}$ and plant diseases and disorders may be related to its indirect effects on general plant health or its direct impacts on plant growth due to its specific physiological roles (Cakmak 2013).

Analysis of $Q$. brantii in various stages of decline showed that the amount of $\mathrm{Mg}$ in the leaf, bark, and wood tissues increased as stress increased. Drought reduces $\mathrm{Mg}$ absorption, which increases $\mathrm{Mg}$ deficiency and the resultant symptoms. Grabřová and Martinková (2001) showed that, during the growth periods of Norway spruce (Picea abies), drought caused a larger reduction in $\mathrm{N}$ and $\mathrm{Mg}$ contents than in $\mathrm{P}$ and $\mathrm{K}$ contents under the same conditions. In addition, drought resulted in reduced $\mathrm{Mg}$ uptake in both the roots and shoots of Spartina alterniflora (Brown et al. 2006).

In all tissues tested in this study, Ca increased as decline severity increased. In plants, $\mathrm{Ca}$ is involved in environmental stress mitigation (Pessarakli et al. 2015). Calcium regulates cell metabolism and is a major component in cell wall structure (Akinci and Simsek 2004). Calcium deficiency may result in increased spread of disease-causing agents in infected plants (Hawkesford et al. 2012), which is partly due to reductions in the physical resistance of plant tissues to penetration by fungal hyphae. The activities of cell wall degrading enzymes in plant pathogenic fungi and bacteria decrease in the presence of excess Ca (Rahman and Punja 2007).

Quantities of $\mathrm{Ca}$ in leaves of declining trees were higher than in healthy trees, which may be due to antagonism between $\mathrm{Ca}$ and $\mathrm{K}$; in cases of $\mathrm{K}$ deficiency, more $\mathrm{Ca}$ is absorbed by the foliage (Gransee and Fuhrs 2013). Further, Ca absorption is highly dependent on transpiration, which is limited in drought stress conditions (Setayeshmehr and Ganjali 2013). Singh and Singh (2004) examined soil nutrient mobility and uptake by Dalbergia sissoo seedlings grown under different irrigation regimens, showing that $\mathrm{Ca}$ concentrations increased considerably in the leaves and roots under severe drought. Hu and Schmidhalter (2005) reported that, in plants under drought conditions, $\mathrm{P}$ and $\mathrm{K}$ absorption decreased considerably, whereas that of $\mathrm{Ca}$ decreased slightly. Analysis of the long-term effects of drought in a Mediterranean evergreen (Quercus ilex-dominated) forest suggested that drought leads to decreases in Ca concentrations in the above-ground biomass, which was attributed to a reduction in transpiration flux (Sardans et al. 2008). 
Phosphorus is an essential mineral nutrient with a key role in conserving and transferring energy in living organisms, and is required in relatively large quantities to maintain plant growth (Amtmann and Blatt 2009). As decline severity increased, the amount of $\mathrm{P}$ in the oak leaves increased. This change may mitigate the impact of stress by reducing the transpiration rate in leaves via controlling the opening and closing of stomata (Hosseini 2017). In stressed Quercus ilex, the quantity of $\mathrm{P}$ increased in leaves and decreased in wood and root tissues, which suggests that $\mathrm{P}$ was actively transported from the stems to the leaves (Sardans and Peñuelas 2007). High concentrations of P in response to induced stress are associated with increased water use efficiency (Diaz-Pereira and Roldán 2000) and elevated stress defense responses (Egilla et al. 2005). Increases in P in leaves of declining oak trees indicated that the plants attempted to actively transport $\mathrm{P}$ from the soil to the crowns and leaves of affected trees to improve water consumption efficiency and protect against crown dieback (Hosseini 2017). In wood and bark samples, increased decline severity led to decreased $\mathrm{P}$ contents. This reduction in $\mathrm{P}$ contents may have also been due to disruption of water-soil relations and the response of trees to stress (Hosseini 2017).

The roles of $\mathrm{Fe}$ in plant growth and development include nitrogen fixation, photosynthesis, the electron transfer system (Bennett 1993), chlorophyll synthesis, and thylakoid function (Imsande 1998). In addition, Fe is involved in defensive reactions to stress (Nikolic and Römheld 1999). Increased Fe content was associated with increased decline severity in the 3 sampled tissues of Q. brantii. Alizadeh et al. (2008) showed that Fe played an active role in defense against some diseases, but it was not as effective as other elements, such as $\mathrm{P}, \mathrm{Mn}, \mathrm{Cu}$ and $\mathrm{Zn}$. Competition between plants and pathogens for $\mathrm{Fe}$ is a factor in the development of disease, as some pathogens require high amounts of $\mathrm{Fe}$ in plant cells (Kieu et al. 2012). Iron uptake increases under stress conditions; therefore, elevated Fe uptake is a potential indicator of plant infection (Martins et al. 2003).

Potassium has a critical role in plant defense against pathogens and pests through its influence on cuticle thickness and bark structure (Amtmann et al. 2008). A reduction in $\mathrm{K}$ availability during bark formation can result in tree weakening and decline (Ahmad et al. 2009). Potassium is involved in metabolism via the regulation of enzyme activities and is a key element regulating stomatal opening and closing (Hawkesford et al. 2012). In this study, increased decline severity was associated with higher $\mathrm{K}$ concentrations in the leaf and sapwood of $Q$. brantii. In contrast, $\mathrm{K}$ concentrations in bark decreased as decline severity increased. Changes in the $\mathrm{K}$ contents of declining trees relative to healthy trees may contribute to weakening of trees. High $\mathrm{K}$ concentrations can have detrimental effects, such as reducing the absorption of $\mathrm{Mg}$ and $\mathrm{Ca}$ (Hawkesford et al. 2012). Mahouachi (2007) found that banana plants exhibited reduced $\mathrm{K}$ contents under drought conditions. In addition, in leaves of water-stressed Olea europaea L. trees, water was a major determinant in the availability of mineral nutrients (including K) from the soil, absorption by plants, and translocation from roots to the shoots regardless of overall nutritional status (RestrepoDiaz et al. 2008). Arquero et al. (2006) showed that K-deficient olive trees under water stress regulated stomatal closure. In addition to its positive impact on tolerance to abiotic stresses, Anschütz et al. (2014) showed that K plays a crucial role in signaling the presence of stress factors, such as drought.

Increased decline severities in $Q$. brantii led to accumulation of increasing quantities of $\mathrm{Na}$ in leaf, bark and sapwood tissues. Quantifying changes in nutrient concentrations in plant tissues is an effective method of evaluating the stress tolerance of plants, and $\mathrm{Na}$ is a particularly important indicator (Bremner and Mulvaney 1982). Absorbing greater 
amounts of $\mathrm{Na}$ enables plants to maintain osmotic balance more effectively by increasing water absorption (Munns and James 2003). Higher levels of stress lead to increased accumulation of $\mathrm{Na}$ in plants. For example, Battie-Laclau et al. $(2013,2014)$ suggested that in Eucalyptus grandis, Na plays a role in the structural and physiological adjustments to drought and improves osmoregulatory and photosynthetic functions.

\section{CONCLUSIONS}

1. This work indicated that the decline of Quercus brantii affects the absorption of nutrients in leaf, bark, and sapwood tissues.

2. The stress response of $Q$. brantii led to changes in the quantities of nutrients absorbed in different tissues. The changes varied across tissue types.

3. Tree decline reduced mass flow-dependent mineral nutrient uptake and subsequent translocation of nutrients from the roots to the shoots. In addition to impaired plant development and reduced vigor, problems with mineral nutrition occurred as secondary effects of tree decline.

4. Improved understanding of the effects of decline on plant nutrition is useful for developing strategies to minimize the damage caused by decline.

\section{ACKNOWLEDGMENTS}

The authors are grateful for the kind cooperation of the Ilam University's main laboratory staff.

\section{REFERENCES CITED}

Ahmad, R., Shouraki, Y. D., and Shafiei, S. (2009). "Nutritional status of Elm (Ulmus glabra Huds.) trees in National Botanical Garden of Iran," Iranian Journal of Forest and Poplar Research 17(1), 99-106.

Akinci, I. E., and Simsek, M. (2004). "Ameliorative effects of potassium and calcium on the salinity stress in embryo culture of cucumber (Cucumis sativus L.)," Journal of Biological Sciences 4(3), 361-365. DOI: 10.3923/jbs.2004.361.365

Alizadeh, A., Majidi, A., and Noormohammadi, G. (2008). "Effects of drought and soil nitrogen on nutrient uptake by of corn varieties 704," Journal of Agricultural Sciences 4(1), 51-59. (In Farsi)

Amtmann, A., and Blatt, M. R. (2009). "Regulation of macronutrient transport," New Phytologist 181(1), 35-52. DOI: 10.1111/j.1469-8137.2008.02666. x

Amtmann, A., Troufflard, S., and Armengaud, P. (2008). "The effect of potassium nutrition on pest and disease resistance in plants," Physiologia Plantarum 133(4), 682-691. DOI: 10.1111/j.1399-3054.2008.01075. x

Anschütz, U., Becker, D., and Shabala, S. (2014). "Going beyond nutrition: Regulation of potassium homoeostasis as a common denominator of plant adaptive responses to 
environment," Journal of Plant Physiology 171(9), 670-687. DOI:

10.1016/j.jplph.2014.01.009

Arquero, O., Barranco, D., and Benlloch, M. (2006). "Potassium starvation increases stomatal conductance in olive trees," HortScience 41(2), 433-436. DOI:

10.21273/HORTSCI.41.2.433

Babaie-Kafaie, S. (2004). "Forests and rangelands role in absorbing greenhouse gas emissions and offer ways to reduce emissions," in: Proceedings of the Third Regional Conference and the First International Conference on Climate Change, Isfahan, Iran, pp. 323-328.

Bal, T. L., Storer, A. J., Jurgensen, M. F., Doskey, P. V., and Amacher, M. C. (2015). "Nutrient stress predisposes and contributes to sugar maple dieback across its northern range: A review," Forestry 88(1), 64-83. DOI: 10.1093/forestry/cpu051

Battie-Laclau, P., Laclau, J.-P., de Cassia Piccolo, M., Arenque, B. C., Beri, C., Mietton, L., Muniz, M. R. A., Jordan-Meille, L., Buckeridge, M. S., and Nouvellon, Y., et al. (2013). "Influence of potassium and sodium nutrition on leaf area components in Eucalyptus grandis trees, " Plant and Soil 371, 19-35. DOI: 10.1007/s11104-0131663-7

Battie-Laclau, P., Laclau, J.-P., Beri, C., Mietton, L., Muniz, M. A., Arenque, B. C., de Cassia Piccolo, M., Jordan-Meille, L., Bouillet, J.-P., and Nouvellon, Y. (2014). "Photosynthetic and anatomical responses of Eucalyptus grandis leaves to potassium and sodium supply in a field experiment," Plant, Cell \& Environment 37(1), 70-81. DOI: $10.1111 /$ pce.12131

Bennett, W. F. (1993). "Plant nutrient utilization and diagnostic plant symptoms," in: Nutrient Deficiencies and Toxicities in Crop Plants, W. F. Bennett (ed.), The APS Press, St. Paul, MN, USA, pp. 1-7.

Bremner, J., and Mulvaney, C. (1982). "Nitrogen - total," in: Methods of Soil Analysis, $2^{\text {nd }}$ Ed: Agronomy Monograph 9, A. L. Page, R. H. Miller, and O. R. Keeney (eds.), ASA and SSSA, Madison, WI, USA, pp. 595-624.

Brown, C. E., Pezeshki, S. R., and DeLaune, R. D. (2006). "The effect of salinity and soil drying on nutrient uptake and growth of Spartina alterniflora in a simulated tidal system," Environmental and Experimental Botany 58(1-3), 140-148. DOI: 10.1016/j.envexpbot.2005.07.006

Bucci, S. J., Scholz, F. G., Goldstein, G., Meinzer, F. C., Franco, A. C., Campanello, P. I., Villalobos-Vega, R., Bustamante, M., and Miralles-Wilhelm, F. (2006). "Nutrient availability constrains the hydraulic architecture and water relations of savanna trees," Plant, Cell \& Environment 29(12), 2153-2167. DOI: 10.1111/j.13653040.2006.01591.x

Burke, J. J. (2007). "Evaluation of source leaf responses to water-deficit stresses in cotton using a novel stress bioassay," Plant Physiology 143(1), 108-121. DOI: 10.1104/pp.106.087783

Cakmak, I. (2013). "Magnesium in crop production, food quality and human health," Plant and Soil 368, 1-4. DOI: 10.1007/s11104-013-1781-2

Clatterbuck, W. K., and Kauffman, B. W. (2005). Managing Oak Decline, Extension SP 675 (Southern Regional Extension Forestry publication SREF-FM-004), The University of Tennessee, Knoxville, TN, USA.

Daroub, S. H., and Snyder, G. H. (2007). "The chemistry of plant nutrients in soil," in: Mineral Nutrition and Plant Disease, L. E. Datnoff, W. H. Elmer, and D. M. Huber (eds.), APS Press, St. Paul, MN, USA, pp. 1-7. 
Diaz-Pereira, E., and Roldán, A. (2000). "Effects of reforestation techniques on the nutrient content, photosynthetic rate and stomatal conductance of Pinus halepensis seedlings under semiarid conditions," Land Degradation and Development 11(5), 475-486. DOI: 10.1002/1099-145X(200009/10)11:5<475::AID-LDR408>3.0.CO;2$\mathrm{M}$

Egilla, J. N., Davies, F. T., and Boutton, T. W. (2005). "Drought stress influences leaf water content, photosynthesis, and water-use efficiency of Hibiscus rosa-sinensis at three potassium concentrations," Photosynthetica 43(1), 135-140. DOI: 10.1007/s11099-005-5140-2

Grabřová, S., and Martinková, M. (2001). "Changes in mineral nutrition of Norway spruce (Picea abies [L.] Karst.) under the impact of drought," Ekologia-Bratislava 20(S1), 46-60.

Gransee, A., and Führs, H. (2013). "Magnesium mobility in soils as a challenge for soil and plant analysis, magnesium fertilization and root uptake under adverse growth conditions," Plant and Soil 368, 5-21. DOI: 10.1007/s11104-012-1567-y

Harpole, W. S., Ngai, J. T., Cleland, E. E., Seabloom, E. W., Borer, E. T., Bracken, M. E. S., Elser, J. J., Gruner, D. S., Hillebrand, H., Shurin, J. B., and Smith, J. E. (2011). "Nutrient co-limitation of primary producer communities," Ecology Letters 14(9), 852-862. DOI: 10.1111/j.1461-0248.2011.01651. x

Hawkesford, M., Horst, W., Kichey, T., Lambers, H., Schjoerring, J., Skrumsager Møller, I., and White, P. (2012). "Functions of macronutrients," in: Marschner's Mineral Nutrition of Higher Plants, $3^{\text {rd }}$ Ed., H. Marschner (ed.), Academic Press, London, England, pp. 135-190. DOI: 10.1016/B978-0-12-384905-2.00006-6

Hosseini, A. (2012). "Infestation of forest trees to the borer beetle and its relation to habitat conditions in the Persian oak (Quercus brantii) in Ilam Province," Iranian Journal of Forest and Range Protection Research 9(1), 53-66.

Hosseini, A. (2017). "Variability of nitrogen and phosphorous in Persian oak trees and soil of dieback affected stands in Ilam," Forest and Wood Products 72(2), 231-240. DOI: 10.22059/jfwp.2017.62480

$\mathrm{Hu}, \mathrm{Y}$., and Schmidhalter, U. (2005). "Drought and salinity: A comparison of their effects on mineral nutrition of plants," Journal of Plant Nutrition and Soil Science 168(4), 541-549. DOI: 10.1002/jpln.200420516

Imsande, J. (1998). "Iron, sulfate, and chlorophyll deficiencies: A need for an integrative approach in plant physiology," Plant Physiology 103(1), 139-144. DOI: 10.1034/j.1399-3054.1998.1030117.x

Jones, J. B., and Huber, D. M. (2007). “Magnesium and plant disease,” in: Mineral Nutrition and Plant Disease, L. E. Datnoff, W. H. Elmer, and D. M. Huber (eds.), APS Press, St. Paul, MN, USA. pp. 95-100. DOI: 10.1007/s11104-012-1476-0

Kabrick, J. M., Dey, D. C., Jensen, R. G., and Wallendorf, M. (2008). "The role of environmental factors in oak decline and mortality in the Ozark Highlands," Forest Ecology and Management 255(5-6), 1409-1417. DOI: 10.1016/j.foreco.2007.10.054

Kieu, N. P., Aznar, A., Segond, D., Rigault, M., Simond-Côte, E., Kunz, C., Soulie, M.C., Expert, D., and Dellagi, A. (2012). "Iron deficiency affects plant defense responses and confers resistance to Dickeya dadantii and Botrytis cinerea," Molecular Plant Pathology 13(8), 816-827. DOI: 10.1111/J.13643703.2012.00790.X

Lakzian, A., Feiziasl, V., Theranifar, A., Halajnia, A., Rahmani, H., Pakdel, P., Mohseni, H., and Talebi, A. (2013). "Evaluation of dieback and early yellowing of Sycamore 
trees (Platanus sp.) in Mashhad by using GGE biplot analysis," Journal of Horticultural Science 27(3), 259-274. DOI: 10.22067/jhorts4.v0i0.26354 (In Farsi)

LeBauer, D. S., and Treseder, K. K. (2008). "Nitrogen limitation of net primary productivity in terrestrial ecosystems is globally distributed," Ecology 89(2), 371-379. DOI: $10.1890 / 06-2057.1$

Long, R. P., Horsley, S. B., Hallett, R. A., and Bailey, S. W. (2009). "Sugar maple growth in relation to nutrition and stress in the northeastern United States," Ecological Applications 19(6), 1454-1466. DOI: 10.1890/08-1535.1

Lukac, M., Calfapietra, C., Lagomarsino, A., and Loreto, F. (2010). "Climate change and tree nutrition: Effects of elevated $\mathrm{CO}_{2}$ and temperature," Tree Physiology 30(9), 1209-1220. DOI: 10.1093/treephys/tpq040

Mahouachi, J. (2007). "Growth and mineral nutrient content of developing fruit on banana plants (Musa acuminata AAA, 'Grand Nain') subjected to water stress and recovery," The Journal of Horticultural Science and Biotechnology 82(6), 839-844. DOI: 10.1080/14620316.2007.11512315

Martins, A. L. C., Bataglia, O. C., Camargo, O. A., and Cantarella, H. (2003). "Corn yield and uptake of $\mathrm{Cu}, \mathrm{Fe}, \mathrm{Mn}$ and $\mathrm{Zn}$ from sewage sludge-amended soil with and without liming," Revista Brasileira de Ciência do Solo 27(3), 563-574. DOI: 10.1590/S0100-06832003000300018

Miles, P. H., Wilkinson, N. S., and McDowell, L. R. (2001). Analysis of Minerals for Animal Nutrition Research, Department of Animal Science, University of Florida, Gainesville, FL, USA.

Munns, R., and James, R. A. (2003). "Screening methods for salinity tolerance: A case study with tetraploid wheat," Plant and Soil 253, 201-218. DOI: 10.1023/a:1024553303144

Niinemets, U. (2010). "Responses of forest trees to single and multiple environmental stresses from seedlings to mature plants: Past stress history, stress interactions, tolerance and acclimation," Forest Ecology and Management 260(10), 1623-1639. DOI: $10.1016 /$ j.foreco.2010.07.054

Nikolic, M., and Römheld, V. (1999). "Mechanism of Fe uptake by the leaf symplast: Is Fe inactivation in leaf a cause of Fe deficiency chlorosis?," Plant and Soil 215, 229237. DOI: $10.1023 / \mathrm{A}: 1004786211779$

Pagter, M., Bragato, C., and Brix, H. (2005). "Tolerance and physiological responses of Phragmites australis to water deficit," Aquatic Botany 81(4), 285-299. DOI: 10.1016/j.aquabot.2005.01.002

Pessarakli, M., Haghighi, M., and Sheibanirad, A. (2015). "Plant responses under environmental stress conditions," Advances in Plants and Agriculture Research 2(6), 276-286. DOI: 10.15406/apar.2015.02.00073

Pourhashemi, M., and Sadeghi, S. M. M. (2021). "A review on ecological causes of oak decline phenomenon in forests of Iran," Ecology of Iranian Forests 8(16), 148-164. (In Farsi)

Rahman, M., and Punja, Z. K. (2007). "Calcium and plant disease," in: Mineral Nutrition and Plant Disease, L. E. Datnoff, W. H. Elmer, and D. M. Huber (eds.), American Phytopathological Society, St. Paul, MN, USA, pp. 79-93.

Restrepo-Diaz, H., Benlloch, M., and Fernández-Escobar, R. (2008). "Plant water stress and $\mathrm{K}^{+}$starvation reduce absorption of foliar applied $\mathrm{K}^{+}$by olive leaves," Scientia Horticulturae 116(4), 409-413. DOI: 10.1016/j.scienta.2008.03.004 
Römheld, V. (2012). "Diagnosis of deficiency and toxicity of nutrients," in: Marschner's Mineral Nutrition of Higher Plants, $3^{\text {rd }}$ Ed., H. Marschner (ed.), Academic Press, London, England, pp. 299-313. DOI: 10.1016/B978-0-12-384905-2.00011-X

Samuelson, L. J., Farris, M. G., Stokes, T. A., and Coleman, M. D. (2008). "Fertilization but not irrigation influences hydraulic traits in plantation-grown loblolly pine," Forest Ecology and Management 255(8-9), 3331-3339. DOI: 10.1016/j.foreco.2008.02.014

Sardans, J., and Peñuelas, J. (2007). "Drought changes phosphorus and potassium accumulation patterns in an evergreen Mediterranean forest," Functional Ecology 21(2), 191-201. DOI: 10.1111/j.1365-2435.2007.01247.x

Sardans, J., Peñuelas, J., and Ogaya, R. (2008). "Drought-induced changes in C and N stoichiometry in a Quercus ilex Mediterranean forest," Forest Science 54(5), 513522. DOI: $10.1093 /$ forestscience/54.5.513

Schaberg, P. G., Tilley, J. W., Hawley, G. J., DeHayes, D. H., and Bailey, S. W. (2006). "Associations of calcium and aluminum with the growth and health of sugar maple trees in Vermont," Forest Ecology and Management 223(1-3), 159-169. DOI: 10.1016/j.foreco.2005.10.067

Setayeshmehr, Z., and Ganjali, A. (2013). "Effects of water stress on growth and physiological characteristics Anethum graveolens L.," Journal of Horticultural Science (Agricultural Sciences and Technology) 27(1), 27-35. (In Farsi)

Silva, E. C., Nogueira, R. J. M. C., Vale, F. H. A., de Melo, N. F., and de Araújo, F. P. (2009). "Water relations and organic solutes production in four umbu tree (Spondias tuberosa) genotypes under intermittent drought," Brazilian Journal of Plant Physiology 21(1), 43-53. DOI: 10.1590/S1677-04202009000100006

Singh, B., and Singh, G. (2004). "Influence of soil water regime on nutrient mobility and uptake by Dalbergia sissoo seedlings," Tropical Ecology 45(2), 337-340.

Šrcelj, H., Tausz, M., Grill, D., and Batic, F. (2005). "Biochemical responses in leaves of two apple tree cultivars subjected to progressing drought," Journal of Plant Physiology 162(12), 1308-1318. DOI: 10.1016/j.jplph.2005.01.018

Talebi, K. S., Sajedi, T., and Pourhashemi, M. (2014). Forests of Iran: A Treasure from the Past, a Hope for the Future, Springer Netherlands, Dordecht, Netherlands.

Tavakolinekou, H., Rahmani, A., Pourmeidani, A., and Adnani, S. M. (2008). "Investigation on soil and water salinity effects on weakness and mortality of Arizona Cypress (Cupressus arizonica G.) in Qom," Iranian Journal of Forest and Poplar Research 16(4), 543-555. (In Farsi)

Vitousek, P. M., Porder, S., Houlton, B. Z., and Chadwick, O. A. (2010). "Terrestrial phosphorus limitation: Mechanisms, implications, and nitrogen-phosphorus interactions," Ecological Applications 20(1), 5-15. DOI: 10.1890/08-0127.1

Ward, E. J., Oren, R., Sigurdsson, B. D., Jarvis, P. G., and Linder, S. (2008). "Fertilization effects on mean stomatal conductance is mediated through changes in the hydraulic attributes of mature Norway spruce trees," Tree Physiology 28(4), 579596. DOI: 10.1093/treephys/28.4.579

Zarin Kafsh, M. (2001). Forest Pedology, Soil and Plant Interaction in Relation to Environmental Factors in Forest Ecosystems, Ministry of Jihad Keshavarzi, Iran.

Article submitted: February, 16, 2021; Peer review completed: April 25, 2021; Revised version received and accepted: April 30, 2021; Published: May 5, 2021.

DOI: 10.15376/biores.16.3.4704-4715 